\title{
Características físico-químicas e bacteriana do fluído ruminal de caprinos criados extensivamente em Mossoró/RN
}

Jucélio S Gameleira[a], Rodolfo G Vale ${ }^{[a]}$, Aluisio Souza-Neto ${ }^{[a]}$, Estela IB Lemos ${ }^{[a]}$, Francisco J.A. Souza[a], Paulo R Firmino[a], Francisco FF Neto ${ }^{[a]}$, Antônio HH Minervino ${ }^{[b]}$, Isabella 0 Barros ${ }^{[c]}$, Raimundo A Barrêto Júnioor ${ }^{[a]^{*}}$

\footnotetext{
[a] Departamento de Ciência Animal, Universidade Federal Rural do Semi-Árido (UFERSA), Mossoró, RN, Brasil

[b] Instituto de Biodiversidade e Floresta, Universidade Federal do Oeste do Pará (UFOPA), Santarém, PA, Brasil

${ }^{[c]}$ Departamento de Ciências Veterinárias, Centro de Ciências Agrárias, Universidade Federal da Paraíba (UFPB), Areia, PB, Brasil
}

*Autor correspondente

e-mail: barreto@ufersa.edu.br

\section{Resumo}

A alimentação dos caprinos no semiárido nordestino está baseada na vegetação nativa, a qual sofre influência da sazonalidade, onde durante o período chuvoso o alimento disponível é abundante e de boa qualidade nutricional, enquanto no período seco, a disponibilidade e qualidade da forragem são reduzidas, interferindo na atividade microbiota e alterando os produtos gerados pela fermentação ruminal, além de influenciar nos parâmetros físico-químicos do fluído ruminal. 0 objetivo do trabalho foi avaliar o efeito da sazonalidade sobre as características físico-químicas (cor, odor, consistência, sedimentação, pH e RAM) e bacteriana (Gram negativa e positiva) do fluído ruminal de caprinos criados extensivamente no município de Mossoró/ RN em quatro períodos distintos no ano de 2014. Foram utilizados 40 caprinos machos, castrados, com seis meses de idade, sem padrão racial definido, vermifugados e vacinados para clostridioses, que pastejavam em área de caatinga durante o dia e eram recolhidos à noite para aprisco, sendo fornecido no cocho apenas água e sal mineral. 0 fluído ruminal foi coletado em quatro períodos distintos: final do período seco (janeiro), meio do período chuvoso (maio), início do período seco (julho) e meio do período seco (outubro). Em cada período foram abatidos 10 caprinos para coleta do fluído ruminal. A precipitação chuvosa do período foi de 8,3 $\mathrm{mm}$ em janeiro, 188,7 mm em maio, $0 \mathrm{~mm}$ em julho e outubro. Os aspectos físicos do fluído ruminal comparados entre os períodos estudados não sofreram influência da sazonalidade ( $P>0,05)$, sendo que a cor variou entre tonalidades de verde, com predominância do verde-oliva no período meio chuvoso $(40 \%)$ e início do seco (30\%) e do verde-castanho nos período meio do seco (30\%) e final do seco (40\%), o odor aromático predominou em todos os períodos e a consistência variou em levemente viscosa e viscosa com sedimentação variando de quatro a oito minutos. A atividade microbiana avaliada pela RAM e o pH não 
apresentaram diferença estatística $(P>0,05)$ entre os períodos avaliados. Houve uma diversidade de formas bacterianas encontrada no fluído ruminal em todos os períodos estudados com predominância de Gramnegativas (cocos, bastonetes curtos) em relação às Gram-positivas (cocos, diplococos e estafilococos). Os aspectos físicos, $\mathrm{pH}$, atividade microbiota e diversidade no fluído ruminal são estabelecidos de acordo com a dieta ofertada ao animal. Nas condições desse estudo, mesmo no período seco quando a disponibilidade e qualidade da forragem são comprometidas em decorrência da estiagem, o desempenho ruminal não foi afetado, o que mostra a qualidade da vegetação da caatinga e a seletividade dos caprinos durante o período avaliado. 